\title{
Octamer-binding factor 6 (Oct-6/Pou3f1) is induced by interferon and contributes to dsRNA-mediated transcriptional responses
}

\author{
Elisabeth Hofmann ${ }^{1}$, Ursula Reichart ${ }^{1}$, Christian Gausterer ${ }^{1,5}$, Christian Guelly², Dies Meijer ${ }^{3}$, Mathias Müller ${ }^{1,4}$, \\ Birgit Strobl ${ }^{1 *}$
}

\begin{abstract}
Background: Octamer-binding factor 6 (Oct-6, Pou3f1, SCIP, Tst-1) is a transcription factor of the Pit-Oct-Unc (POU) family. POU proteins regulate key developmental processes and have been identified from a diverse range of species. Oct-6 expression is described to be confined to the developing brain, Schwann cells, oligodendrocyte precursors, testes, and skin. Its function is primarily characterised in Schwann cells, where it is required for correctly timed transition to the myelinating state. In the present study, we report that Oct-6 is an interferon (IFN)-inducible protein and show for the first time expression in murine fibroblasts and macrophages.

Results: Oct- 6 was induced by type I and type II IFN, but not by interleukin- 6 . Induction of Oct- 6 after IFN $\beta$ treatment was mainly dependent on signal transducer and activator of transcription 1 (Stat1) and partially on tyrosine kinase 2 (Tyk2). Chromatin immunopreciptitation experiments revealed binding of Stat1 to the Oct-6 promoter in a region around $500 \mathrm{bp}$ upstream of the transcription start site, a region different from the downstream regulatory element involved in Schwann cell-specific Oct-6 expression. Oct- 6 was also induced by dsRNA treatment and during viral infections, in both cases via autocrine/paracrine actions of IFN $\alpha / \beta$. Using microarray and RT-qPCR, we furthermore show that Oct- 6 is involved in the regulation of transcriptional responses to dsRNA, in particular in the gene regulation of serine/threonine protein kinase 40 (Stk40) and U7 snRNAassociated Sm-like protein Lsm10 (Lsm10).
\end{abstract}

Conclusion: Our data show that Oct- 6 expression is not as restricted as previously assumed. Induction of Oct- 6 by IFNs and viruses in at least two different cell types, and involvement of Oct- 6 in gene regulation after dsRNA treatment, suggest novel functions of Oct- 6 in innate immune responses.

\section{Backgound}

Type I interferons (IFN $/ \beta)$ are pleiotropic cytokines that exhibit antiviral, antiproliferative and immunomodulatory effects $[1,2]$. IFN $\alpha / \beta$ signal through the Janus kinase (Jak)/signal transducer and activator of transcription (Stat) cascade $[3,4]$. Upon binding of IFN $\alpha / \beta$ to its $\operatorname{cog}$ nate receptor (consisting of Ifnar1 and Ifnar2) a series of phosphorylation events exerted by the associated kinases Jak1 and Tyk2 leads to the activation and nuclear translocation of mainly Stat1/Stat2 heterodimers. Stat $1 /$ Stat 2 together with IFN regulatory factor 9 (Irf9) form the

\footnotetext{
* Correspondence: birgit.strobl@vetmeduni.ac.at

'Institute of Animal Breeding and Genetics, University of Veterinary Medicine Vienna, Vienna, Austria

Full list of author information is available at the end of the article
}

transcription factor complex IFN-stimulated gene factor 3 (ISGF3), which binds to promoters containing an interferon stimulated response element (ISRE, [5]). To a lesser extent Stat 1 homodimers are activated and induce the expression of genes containing an IFN $\gamma$ activated site (GAS, [5]) in their promoter. Type II IFN (IFN $\gamma$ ) activates mainly Stat1 homodimers, low levels of ISGF3 [6,7] and induces an overlapping but not identical set of genes as type I IFNs $[4,8]$. Additional Stats (e.g. Stat3, Stat5) may also be activated by both type I and type II IFNs in a more cell type-restricted manner, but their contribution to IFN-triggered responses is less well established [9]. In addition to the so-called canonical Jak/Stat pathway, other signalling cascades can be activated and impact on gene regulation [4]. Hundreds of IFN stimulated genes 
(ISGs), many of them still poorly characterised [10,11], mediate the complex biological responses to IFNs.

Oct-6 (Pou3f1, SCIP, Tst-1) is a member of the PitOct-Unc (POU) family of transcription factors [12,13]. These proteins are characterised by the highly conserved structure of their DNA-binding domain, the POUdomain, consisting of a POU-specific domain and a POU-homeodomain. Consequently, POU-domain transcription factors recognise a common motif, the octamer consensus motif (ATGCAAAT; [12]). Members of this family are involved in a variety of cellular processes, ranging from house-keeping gene function (Oct-1) to programming of embryonic stem cells (Oct-4), development of the immune system (Oct-1 and Oct-2), of the pituitary gland (Pit-1) or of the nervous system (Brn-1 through -4 and Oct-6). Oct- 6 belongs to the POU protein class III family, whose members are mainly involved in neuronal development [13]. Oct-6 expression is considered cell type-restricted and has so far been described in embryonic stem cells $[14,15]$, developing neural and glial cells [16], cells of neonatal testes [17], squamous epithelia [18], proliferating epidermal keratinocytes [19], and pancreatic $\beta$-cells [20]. Oct- 6 function is mainly characterised in Schwann cells $[21,22]$ and considerably less is known about its role in other cell types. Oct-6 is crucial for the terminal differentiation of myelinating Schwann cells and is required for the expression of early growth response protein 2 (Egr2/Krox20), another transcription factor critical for Schwann cell development $[23,24]$. Oct-6-deficient mice display severe defects in peripheral nerve myelination and, in addition, die soon after birth from a breathing insufficiency caused by defective migration and differentiation of certain neurons in the brainstem [21,22]. Mice with a Schwann cell-specific Oct-6 knockout (i.e. deletion of the Schwann cell-specific enhancer element, SCE) are viable and have severe myelination defects in the peripheral nervous system, as Schwann cells are transiently arrested in the promyelinating stage [25]. Mice expressing Oct-6 constitutively in Schwann cells show a persistent block in myelination [26]. These mice have normal levels of Egr2, but the levels of myelin genes such as myelin protein zero $(M p z)$, myelin basic protein $(M b p)$, and peripheral myelin protein $22(P m p 22)$ are significantly reduced [26]. Thus Oct-6 exerts activating as well as repressing functions during myelination and correctly timed, transient expression of Oct- 6 is crucial for the development of myelinating Schwann cells. Although Oct- 6 is also expressed in oligodendrocytes, Oct-6-deficient mice do not show any myelination defects in the central nervous system, supposedly due to functional redundancies with other co-expressed members of the POU protein class III family [27]. However, transgenic overexpression of Oct-6 in oligodendrocytes causes defective myelination and severe neurological disease, arguing for an impact of at least de-regulated Oct- 6 on central nervous system myelination [28].

Here, we show for the first time cytokine inducibility of Oct- 6 and its expression in cell types other than those described before. Oct- 6 expression was observed in fibroblasts and macrophages in response to type I and type II IFN, during viral infections, and after treatment with the dsRNA analogue poly(I:C). We demonstrate that the IFN $\beta$-mediated induction is Stat 1 -dependent and we identify a Stat1-binding region in the Oct- 6 promoter. In addition, we compared the transcriptomes of wild type (WT) and Oct-6-deficient macrophages and show an involvement of Oct- 6 in the transcriptional control of a subset of poly(I:C) responsive genes.

\section{Results}

Oct- 6 is induced by IFN $\beta$ treatment in fibroblasts and in a Schwann cell line

Expression profiling of Tyk2-deficient fibroblast cell lines revealed that Oct- 6 is a gene being strongly induced by IFN $\beta$ and that depends on the presence of Tyk2 for its full expression (C. Gausterer, B. Strobl et al., unpublished). Since neither IFN inducibility nor expression of Oct-6 in fibroblasts has been described before, we confirmed data in primary embryonic fibroblasts (pMEF) using RT-qPCR analysis. Oct-6 mRNA expression was clearly induced by IFN $\beta$ treatment and induction was reduced in the absence of Tyk2 (Figure 1A). Induction of Oct- 6 was lower than observed for the known IFN target gene $\mathrm{C}-\mathrm{X}-\mathrm{C}$ motif chemokine 10 (Cxcl10/IP-10, Figure $1 \mathrm{~B})$, one of the genes most strongly induced by IFNs. In order to test if Oct-6 expression in fibroblasts is also detectable at the protein level, we performed immunoprecipitation experiments. Oct- 6 protein was clearly induced by IFN $\beta$ treatment (Figure $1 \mathrm{C}$ ). In untreated cells, Oct-6 protein could not be detected, a background band appeared at the same intensity and similar molecular weight as in Oct-6-deficient cells. We next tested Oct-6 DNA-binding activity with EMSAs using an oligonucleotide that contains an octamer consensus motif. As shown in Figure 1D, three DNA-binding complexes were found in IFN $\beta$ treated pMEFs. The fastest migrating complex was only observed after treatment with IFN $\beta$ and was hardly detectable in Tyk2-deficient cells. This complex was identified as Oct- 6 by supershift with a specific antibody (see additional file 1 ) and by its absence in Oct- $6^{-1-}$ cells after IFN $\beta$ treatment (Figure 1E). The two other complexes were present in all samples irrespective of genotype and treatment. The slowest migrating complex was identified as the ubiquitously expressed Oct-1, the other one could so far not be assigned to a specific octamer-binding protein and did not supershift with Oct-1, Oct-2 or Oct-6 specific antibodies (see additional file 1). 


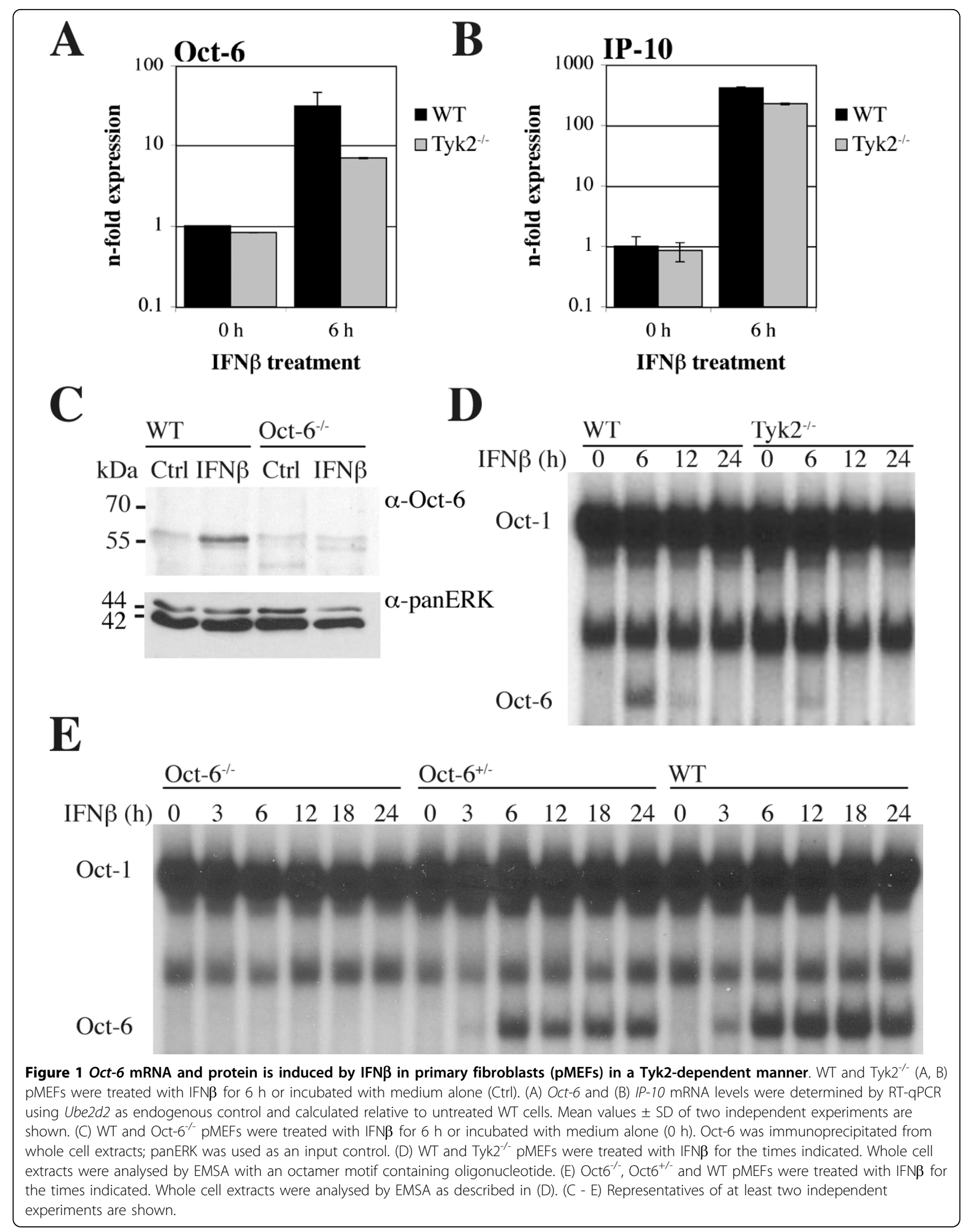


Of note, duration of Oct- 6 expression in response to IFN $\beta$ appeared consistently different in cells derived from mice with distinct genetic backgrounds (compare WT in Figure 1D and Figure 1E).

Since Oct-6 expression and function is best characterised in developing Schwann cells, we analysed whether IFN $\beta$ can induce Oct- 6 expression in this cell type. IFN $\beta$ treatment of the murine Schwann cell line SW10 resulted in a rapid and clear increase of Oct-6 and $I P-10$ mRNAs (Figure $2 \mathrm{~A}$ and $2 \mathrm{~B}$ ). Oct- 6 protein was detectable by EMSA at around $3 \mathrm{~h}$ to $8 \mathrm{~h}$ after IFN $\beta$ stimulation, although levels were consistently quite low (Figure 2C). In accordance with their immature phenotype [29], Oct-6 DNA-binding activity was not detectable in untreated SW10 cells (Figure 2C).

\section{Oct- 6 is induced by IFN $\beta$ and IFN $\gamma$ in macrophages}

Macrophages are important cells of the immune system and their response to IFN $\beta$ is crucial in many infection and disease models. We thus tested bone marrowderived macrophages (BMMs) for Oct-6 expression. Oct-6 mRNA and DNA-binding activity were clearly induced by IFN $\beta$ in macrophages (Figure $3 \mathrm{~A}$ and $3 \mathrm{~B}$ ). Similar to MEFs, induction of Oct-6 DNA-binding was detectable with EMSA from $3 \mathrm{~h}$ IFN $\beta$ treatment onwards (Figure 3A), and Oct-6 was not detectable in untreated cells. Again, identity of Oct- 6 was confirmed with anti-Oct- 6 supershifts and, additionally, by demonstrating migration behaviour of overexpressed Oct- 6 in EMSAs (Figure 3A). Consistent with what has been shown previously [30], constitutive Oct-1 and Oct-2 protein expression was observed in macrophages, as proven by supershift with specific antibodies (Figure $3 A)$. Notably, Oct-6 protein expression and DNA- binding activity was considerably higher in macrophages than in fibroblasts and SW10 cells. Since IFN $\gamma$ also induces several genes that are induced by IFN $\alpha / \beta$, we tested whether Oct- 6 is also induced by IFN $\gamma$. In addition, we analysed Oct- 6 expression in response to interleukin-6 (IL-6), another cytokine that utilises the Jak/ Stat signalling cascade but results in distinct cellular responses. IFN $\gamma$, which mainly activates Stat1, induced Oct-6 mRNA (Figure 3B), Oct-6 protein (Figure 3D) and DNA-binding activity (Figure $3 \mathrm{C}$ ) to slightly lower levels as observed in response to IFN $\beta$. In contrast, IL-6 which mainly signals via Stat3, did not result in detectable Oct-6 DNA-binding activity (Figure 3C).

\section{Oct- 6 expression is dependent on Stat 1 and partially dependent on Tyk2}

To determine if Oct- 6 induction by IFN occurs via the canonical Jak/Stat signalling cascade, macrophages derived from mice deficient for specific Jak/Stat components were analysed. As expected, Oct- 6 was not upregulated by IFN $\beta$ in cells lacking the IFN $\alpha / \beta$ receptor subunit Ifnar1, excluding the possibility that effects are mediated by any other component that might be present in the IFN $\beta$ preparation (Figure 4A). As in MEFs (Figure 1C), Oct-6 induction was partially dependent on the presence of Tyk2 (Figure 4A). Importantly, Oct-6 was hardly detectable in cells lacking Stat1 (Figure 4A), although low level of Oct- 6 was consistently detectable after $24 \mathrm{~h}$ IFN $\beta$ treatment. Thus, Oct- 6 induction occurs mainly in a Stat1-dependent manner. Stat1 induces transcription of interferon regulatory factor 1 (Irf1), a transcription factor that can bind to ISREs and is required for the regulation of a subset of IFN-responsive genes [31]. No difference in Oct-6 mRNA expression was

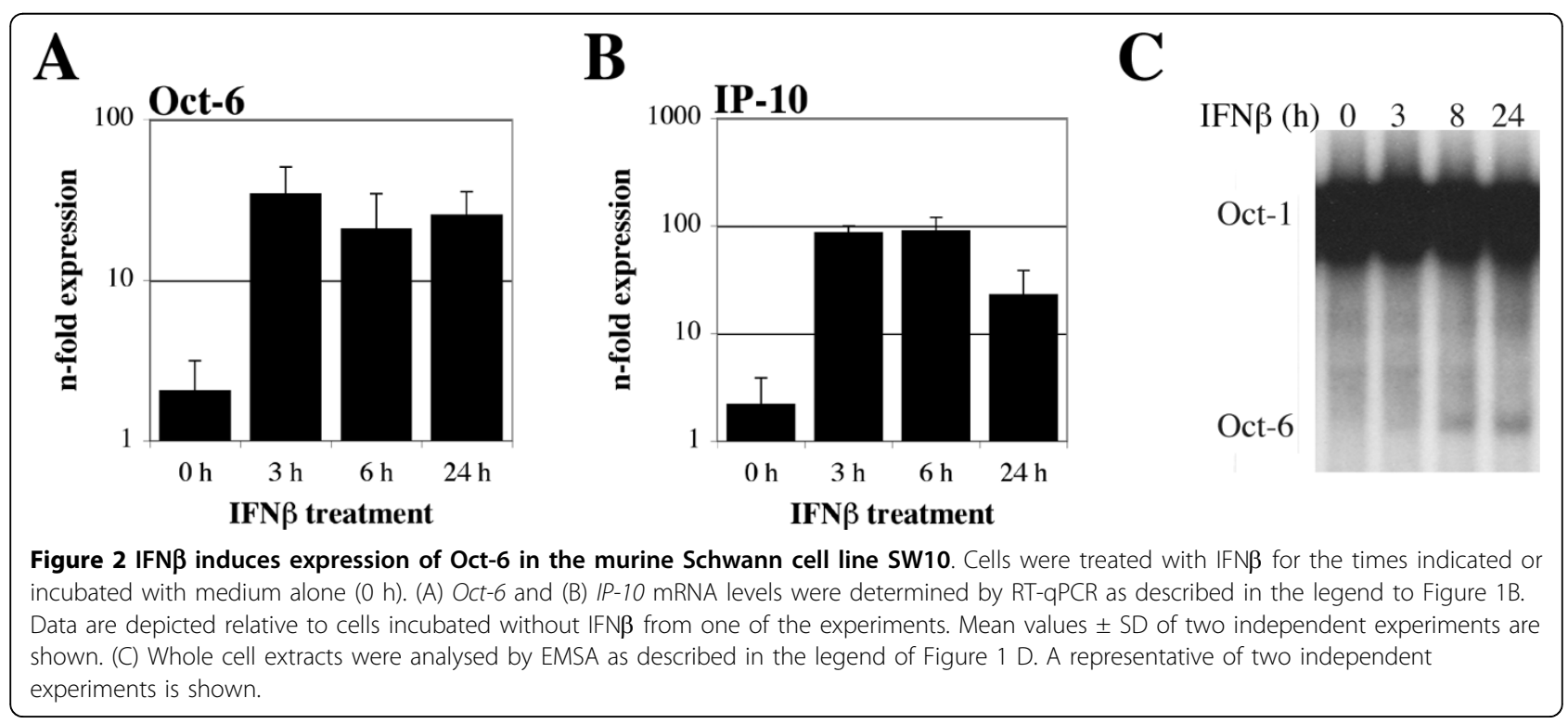




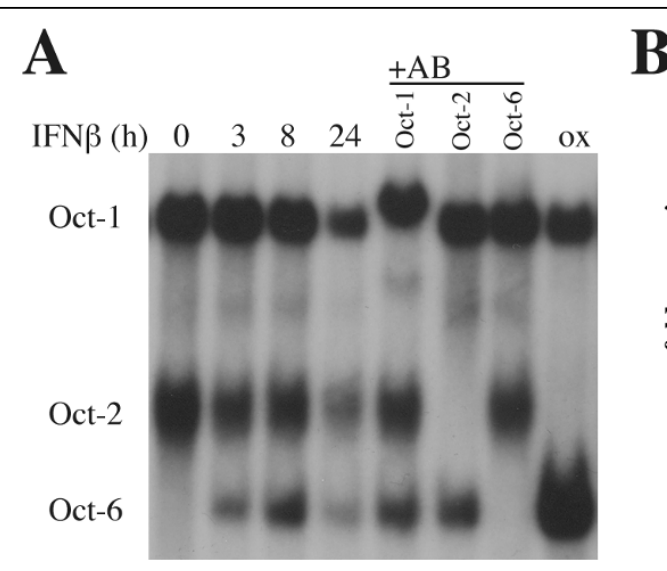

C

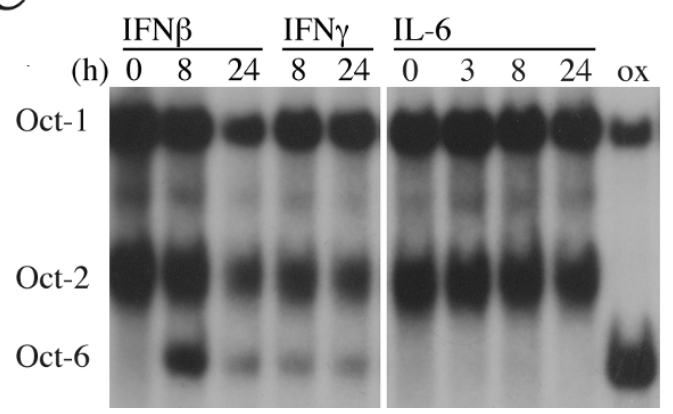

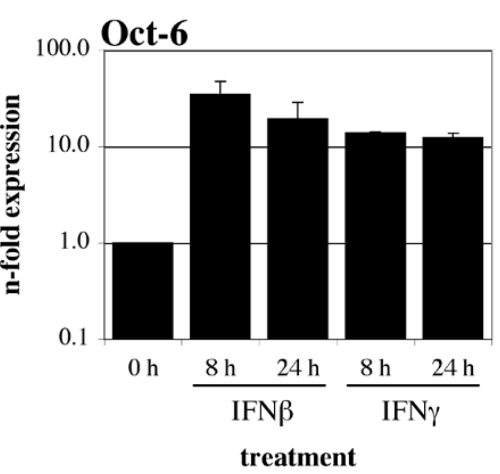

D

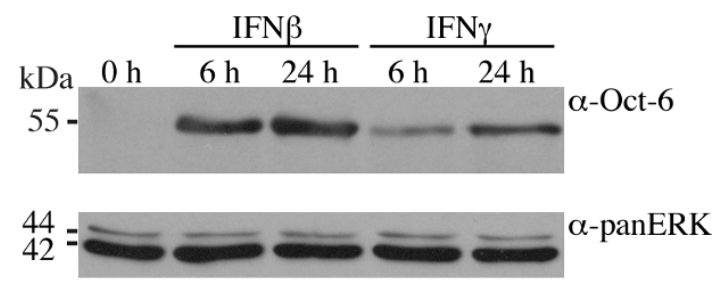

Figure 3 Oct- 6 is induced by IFN $\beta$ and IFN $\boldsymbol{\gamma}$ in macrophages. WT BMMs were treated with IFN $\beta$, IFN $\gamma$ or IL-6 for the times indicated. (A, C) Whole cell extracts were analysed by EMSA as described in the legend of Figure 1 D. (A) DNA-binding complexes were identified by supershift of WT_8 h lysates with the respective antibodies (+AB), and by Oct-6 overexpression (ox) in a MEF cell line. (B) Oct-6 mRNA levels were determined by RT-qPCR as described in the legend of Figure 1A. Mean values \pm SD of two experiments are shown. (D) Oct-6 was immunoprecipitated from whole cell extracts, panERK was used as an input control. (A, C, D) Representatives of at least two independent experiments are shown.

found in Irf1-deficient as compared to WT cells, indicating direct involvement of Stat1 in the transcriptional activation of the Oct-6 gene (Figure 4B).

\section{Oct- 6 is induced by poly $(\mathrm{I}: \mathrm{C})$ treatment and during viral infection via autocrine/paracrine IFN $\alpha / \beta$ signalling}

We next tested whether Oct- 6 is also induced by pathogen recognition receptor (PRR) signalling in an IFN $\alpha / \beta$ dependent or -independent manner [32,33]. To this end, macrophages were either treated with poly(I:C), a synthetic dsRNA analogue, or infected with Murine Cytomegalovirus (MCMV), both strong inducers of IFN $\alpha / \beta$. As shown in Figure 5A and 5B, Oct-6 DNA-binding activity was upregulated in both scenarios. In order to determine whether Oct- 6 is induced directly by PRR signalling, e.g. via $\mathrm{NF} \kappa \mathrm{B}$ or Irf3 transcription factor activation [32,33], we analysed Ifnar1-, IFN $\beta$-, Tyk2- and Stat1-deficient macrophages in response to poly(I:C). Oct-6 expression was completely dependent on Ifnar 1 , demonstrating that Oct-6 expression after poly(I:C) treatment is mediated by autocrine/paracrine actions of IFN $\alpha / \beta$ (Figure $5 \mathrm{C}$ ). Thus, in contrast to several other
ISGs (e.g. IP-10), Oct-6 induction is strictly dependent on the presence of functional IFN $\alpha / \beta$ signalling. Unlike the residual Oct- 6 induction observed after treatment with high amounts of exogenous IFN $\beta$ (Figure 4A), Oct- 6 was not detectable in poly(I:C) treated Stat $1^{-1-}$ cells (Figure 5C). Similarly, Tyk2 dependence was much more pronounced under these conditions than after treatment with high dose of exogenous IFN $\beta$. Delayed induction was observed in cells deficient for IFN $\beta$ (Figure 5C), which is consistent with the prominent role of IFN $\beta$ in the IFN $\alpha / \beta$ amplification loop mainly described in the context of viral infections [34]. Similar results with respect to the requirement of the above analysed signalling molecules were obtained after MCMV infections (see additional file 2).

\section{Stat 1 binds to the Oct- 6 promoter}

We next analysed the Oct-6 promoter for potential Stat1binding sites (ISRE and GAS, respectively). Based on the assumption that conservation argues for functionality of consensus motifs, we analysed mouse, rat and human aligned sequences upstream of the respective transcription 


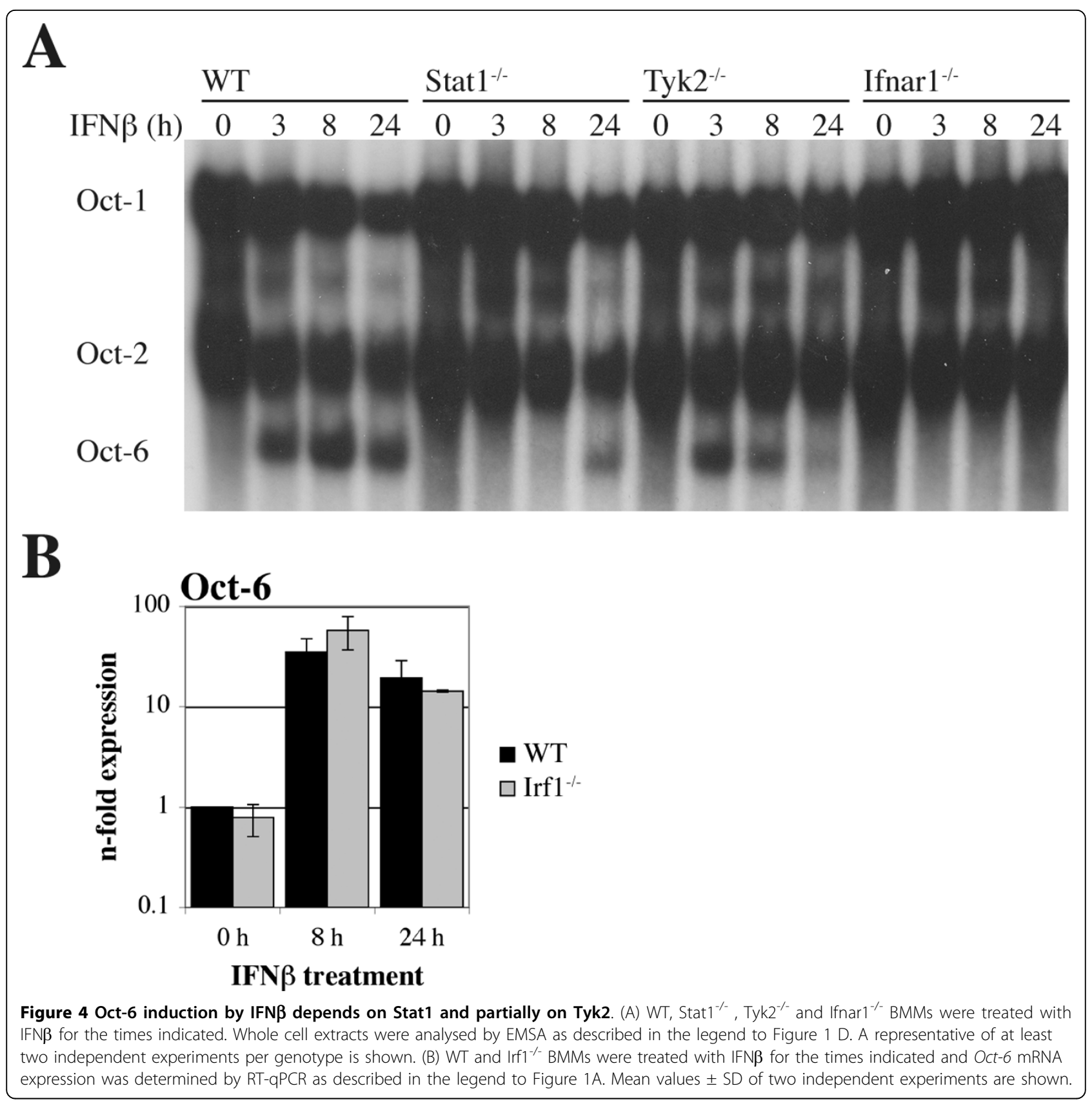

start sites. Within a homologous sequence part of Oct-6, one GAS (-477 to -468$)$ and one ISRE (-412 to -409$)$ was predicted by TFBS analysis using "Patch", a publicly available program scanning input sequences for potential TFBSs based on the Transfac database. Another GAS $(-402$ to -392$)$ located in close proximity to the predicted ISRE was found by checking the sequences next to the predicted sites manually. The GAS elements (Figure 6A) show only one mismatch each compared to the consensus sequence (TTC $\left.(\mathrm{N})_{2-4} \mathrm{GAA},[5]\right)$. The predicted ISRE (-412 to -409$)$ seems rather imperfect when compared to the published consensus motif (GATTTC(N) $)_{2}$ TTCNY, [5]), but is identical to the Transfac annotated ISGF3 motif (GGAAA). To explore the possibility of Stat1-binding to this region, chromatin immunoprecipitation (ChIP) experiments were performed. In accordance with the mRNA induction, increased Stat1-binding to the Oct-6 promoter was observed in response to both IFN $\beta$ and IFN $\gamma$. Stat1-binding was observed with two different PCR reactions, encompassing the regions -481 to -387 or -481 to -243 , respectively (Figure $6 \mathrm{~B}$, see Figure $6 \mathrm{~A}$ for positions of primers used). As a control, Stat1-binding to a 


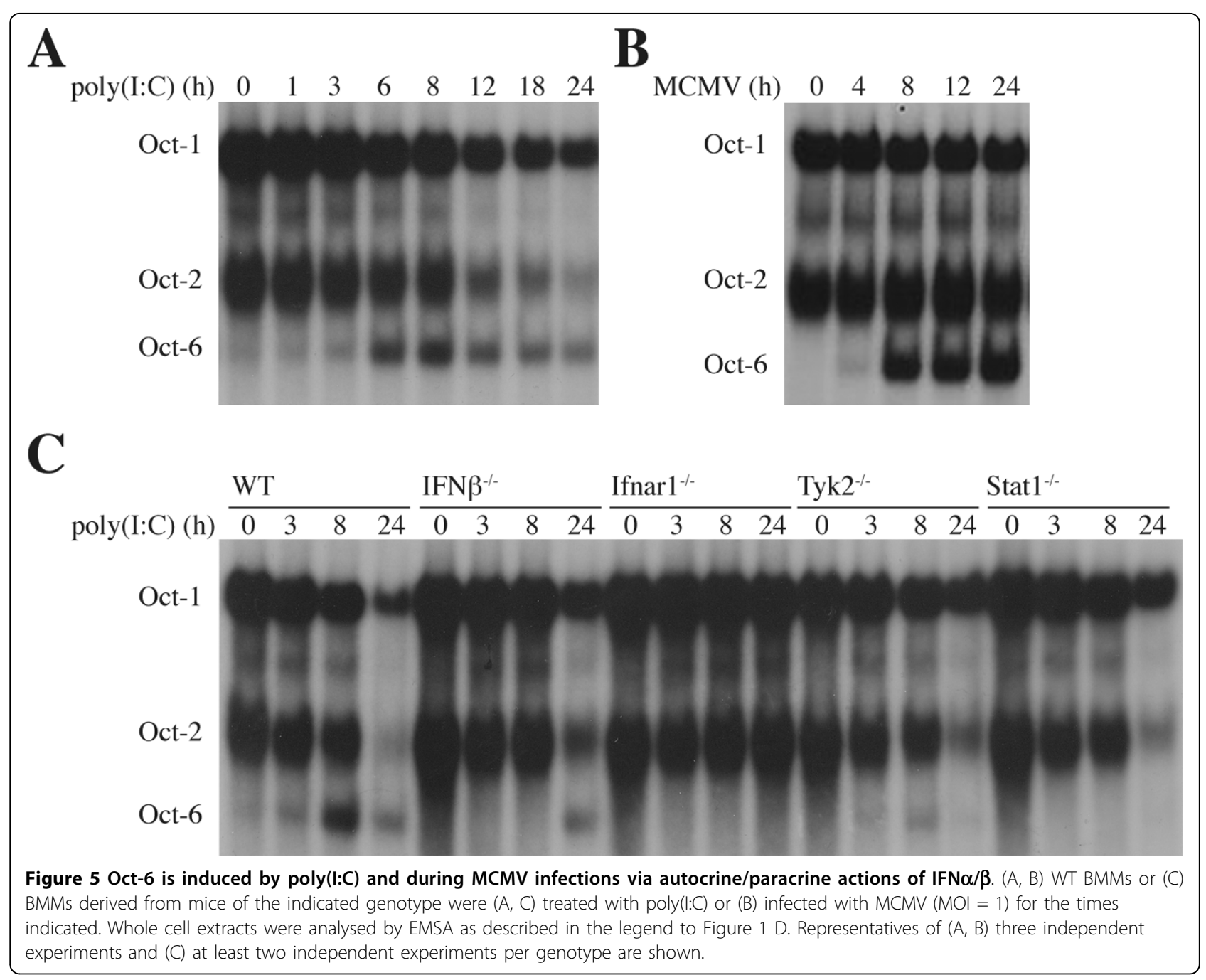

well-characterised binding region in the Irf1 promoter was performed and showed the expected pattern (Figure 6B) [35]. Thus, Stat1 directly binds to the Oct-6 promoter upstream of the transcription start site, most likely at the predicted GAS and/or ISRE site(s) in the region from position -481 to -387 .

IFN $\beta$ and poly $(I: C)$ induced Oct- 6 localises to the nucleus Oct- 6 contains a nuclear localisation and a nuclear export signal, both located in the POU homeodomain $[36,37]$. Although so far no post-translational modifications that direct Oct- 6 to the nucleus have been identified, it has been hypothesised that its transcriptional activity can be controlled by regulating its subcellular localisation [36]. We therefore tested Oct-6 localisation after IFN $\beta$ and poly $(\mathrm{I}: \mathrm{C})$ treatment using immunofluorescence analysis. As expected, Oct-6 was not detected in untreated cells (Figure 7 top panel). In response to IFN $\beta$ and poly(I:C), Oct-6 staining was exclusively found in the nuclei (Figure 7). Hence, both IFN $\beta$ and poly(I:C) are sufficient to induce Oct- 6 expression and nuclear localisation in macrophages.

\section{Absence of Oct- 6 in marcrophages does not influence the expression of Egr2, Pmp22 and IFN $\alpha \beta$ mRNAs}

In order to investigate the biological function of Oct-6, we firstly analysed mRNA expression of potential target genes in the presence or absence of Oct- 6 . Since Oct$6^{-1-}$ mice die soon after birth, foetal livers were used to isolate Oct- $6^{-1-}$ and WT macrophages, respectively. Similar to MEFs and BMMs, Oct-6 expression was not detectable by immunoprecipitation in untreated foetal liver-derived macrophages (FLMs), whereas it was clearly expressed after poly(I:C) treatment (Figure 8A). Inducibility of Oct- 6 by poly $(\mathrm{I}: \mathrm{C})$ was similar to that observed in BMMs as analysed by EMSA (see additional file 3). Among the known target genes in Schwann cells, we analysed expression of Egr2 and peripheral myelin 


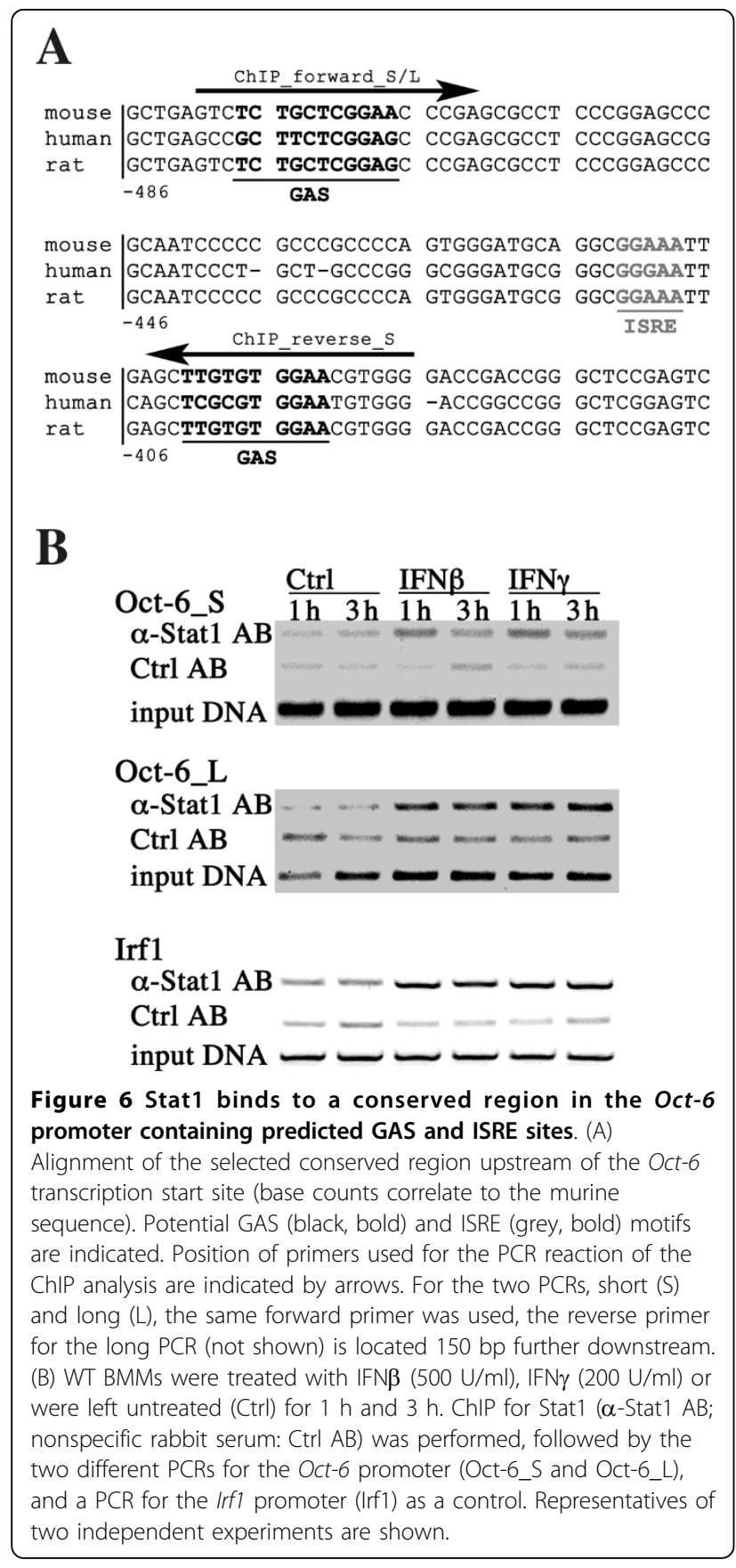

protein $22($ Pmp22) in response to poly(I:C). As shown in Figure $8 \mathrm{~B}$ and $8 \mathrm{C}$, poly $(\mathrm{I}: \mathrm{C})$ treatment resulted in a modest but Oct-6-independent down-regulation of both mRNAs. Octamer consensus motifs and Oct-1 have been implicated in negative regulation of IFN $\alpha$ and IFN $\beta$ gene expression [38]. Furthermore, transient transfection of Oct-6 resulted in a strong upregulation of type I IFN mRNAs (see additional file 4). However, we did not observe any difference in the poly(I:C)-induced expression of IFN $\beta$ or IFN $\alpha$ s (all subtypes, panIFNo)

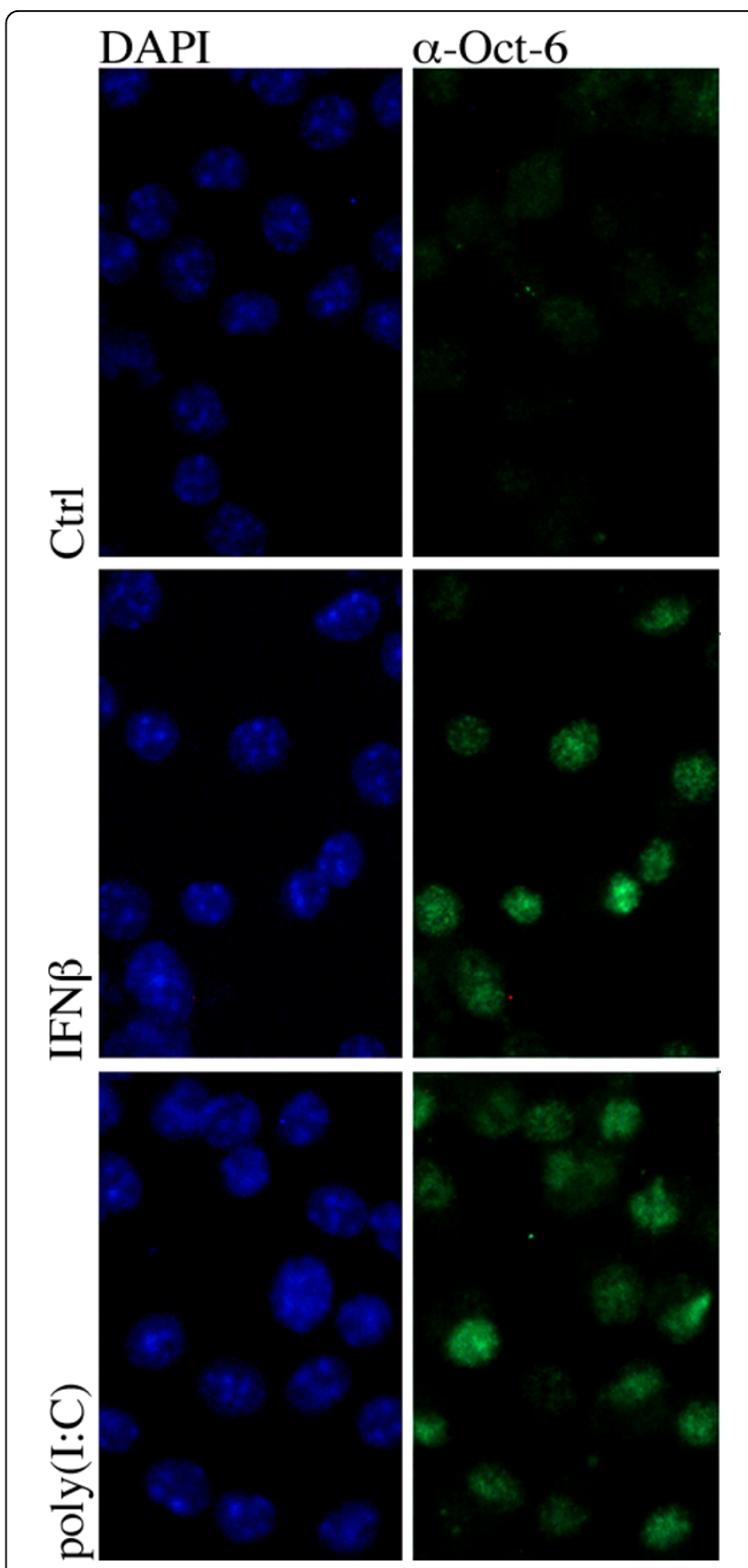

Figure 7 Oct- 6 localises to the nucleus in response to IFN $\beta$ or poly (I:C). WT BMMs were grown on glass slides, treated with IFN $\beta$ (middle panels) or poly(l:C) (lowest panels) for $6 \mathrm{~h}$ or left untreated (upper panels). Oct- 6 was detected by indirect immunofluorescence (right panels), nuclei were stained with DAPI (left panels).

Representatives of two independent experiments are shown.

between Oct $^{-1-}$ and WT macrophages (Figure 8D and $8 \mathrm{E})$. Similarly, no Oct-6-specific effects on the expression of type I IFNs were found in response DNA transfection in fibroblasts (see additional file 5).

Octamer proteins can influence viral replication [12] and the high induction of Oct- 6 that we observed after 


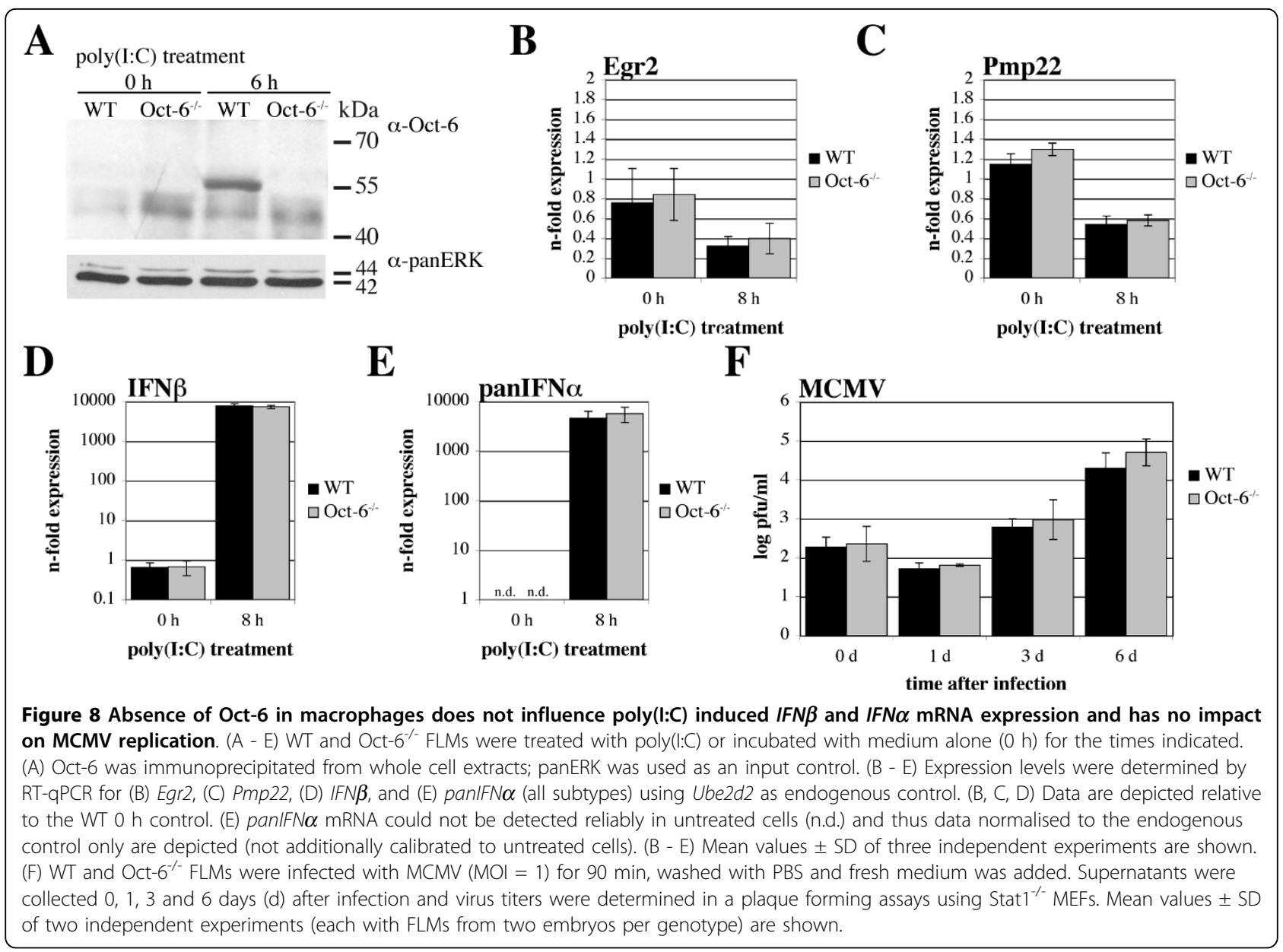

MCMV infection in macrophages, prompted us to analyse MCMV replication in the presence or absence of Oct-6. WT and Oct-6-deficient macrophages were infected with MCMV and virus titer was measured over time. No difference in viral yield was observed after infection with a multiplicity of infection (MOI) of 1 (Figure $8 \mathrm{~F}$ ) or a MOI of 0.1 (see additional file 6).

\section{Oct- 6 contributes to the regulation of a subset of genes} in response to poly(l:C) in macrophages

In order to identify target genes of Oct- 6 in the context of innate immune responses, WT and Oct- $6^{-1-}$ FLMs were treated with poly $(\mathrm{I}: \mathrm{C})$ for $8 \mathrm{~h}$ and transcriptional responses were monitored using microarray analysis. A subset of genes $(n=200)$ displayed a significant, at least two-fold difference between WT and Oct- $6^{-/-}$macrophages after poly(I:C) treatment $(p<0.05)$. About $60 \%$ of the genes were reduced, the rest enhanced in the absence of Oct- 6 , arguing for activating as well as repressing functions of Oct-6. Of the differentially expressed genes, 158 could be annotated, remaining probe sequences correlate to RIKEN cDNAs, or cDNAs of unknown function. About half of the differentially expressed genes $(n=96)$ could be grouped into classes/ pathways using functional annotation and clustering (see additional file 7; see additional file 8 for the complete list of differentially expressed genes). The largest group was "Regulation of transcription" containing 15 genes, most of them down-regulated in the absence of Oct- 6 , such as Ctnnd2, Rcor3 and a number of zinc finger proteins. A related category "RNA splicing" contained 3 genes, Sfrs 14, Lsm10 and Sf3a1, all of which showed reduced expression in the absence of Oct-6. Another category "Ubiquitin cycle" contained 6 genes, half of which were up-, half down-regulated. However, analyses for pathway enrichment did not yield any significant results, most likely because the number of differentially regulated genes was too low compared to the vast amount of GO-categories. Nevertheless, the data clearly show that Oct-6 is involved in the regulation of transcriptional responses to poly $(\mathrm{I}: \mathrm{C})$. As expected, in WT cells poly(I:C) treatment had a major effect on the transcriptome with around 3500 genes (out of 12220 genes included in the analysis) significantly regulated $(p<0.05$, 
minimal fold-change of 2). According to Gene Ontology (GO) annotation (GeneSpring Expression Analysis 7.3.1 tool, Agilent Technologies), genes involved in immune responses and cell death were significantly enriched in the set of genes up-regulated in response to poly $(\mathrm{I}: \mathrm{C})$ treatment (see additional file 9, sheet 1: Gene Ontology categories up-regulated by poly $(\mathrm{I}: \mathrm{C})$ treatment in WT cells). In the set of genes down-regulated in response to poly $(\mathrm{I}: \mathrm{C})$ treatment, genes involved in metabolism and cell cycle progression were significantly enriched (see additional file 9, sheet 2: GO categories down-regulated by poly(I:C) treatment in WT cells).

\section{Oct-6 regulates the expression of Stk40 and Lsm10 in response to poly(I:C)}

In order to confirm the role of Oct- 6 in the transcriptional regulation of poly(I:C) responses, we validated expression patterns of serine/threonine kinase 40 (Stk40) and U7 snRNP-specific Sm-like protein LSM10 (Lsm10) with RT-qPCR. Both genes showed around two-fold reduced expression levels in the absence of Oct-6 in the microarray experiment $(p<0.01$, see additional file 7). As shown in Figure 9A, Stk40 was induced about seven-fold in WT cells after poly(I:C) treatment, whereas the induction was only three-fold in Oct $-6^{-/-}$ macrophages. Lsm10 was not significantly influenced by poly(I:C) treatment in WT cells, but its expression was reduced by two-fold in the absence of Oct- 6 (Figure 9B). For both genes, differences in expression between WT and Oct- $6^{-1-}$ macrophages after poly(I:C) treatment were again highly significant $(p<0.01)$.

\section{Discussion}

In this study we report for the first time expression of Oct6 in fibroblasts and macrophages. We show that Oct- 6 is induced by IFN $\beta$ and IFN $\gamma$, but not by IL-6. Expression of Oct-6 in response to IFN $\beta$ occurs mainly via the canonical $\mathrm{Jak} /$ Stat signalling cascade and is dependent on the presence of Stat1 and to a lesser extent on Tyk2. Notably, we observed delayed and low levels of Oct- 6 induction in the absence of Stat1 in response to high dose of exogenous IFN $\beta$, suggesting that additional IFN activated factors can mediate Oct-6 induction. Oct- 6 is also expressed during viral infection and after treatment with the synthetic dsRNA analogue poly(I:C), in both cases mediated by autocrine/paracrine IFN $\alpha / \beta$ signalling. Using ChIP technology, we show that Stat1 directly binds to the Oct-6 promoter at around 387 to $481 \mathrm{bp}$ upstream of the transcription start site, a region containing three conserved Stat 1 consensus binding sites (i.e. two GAS sites and one imperfect ISRE). The presence of GAS and ISRE in the Oct-6 promoter is consistent with the responsiveness to IFN $\gamma$ and IFN $\beta$, a feature that is shared with several other IFN responsive genes. In contrast to the upstream Stat1-

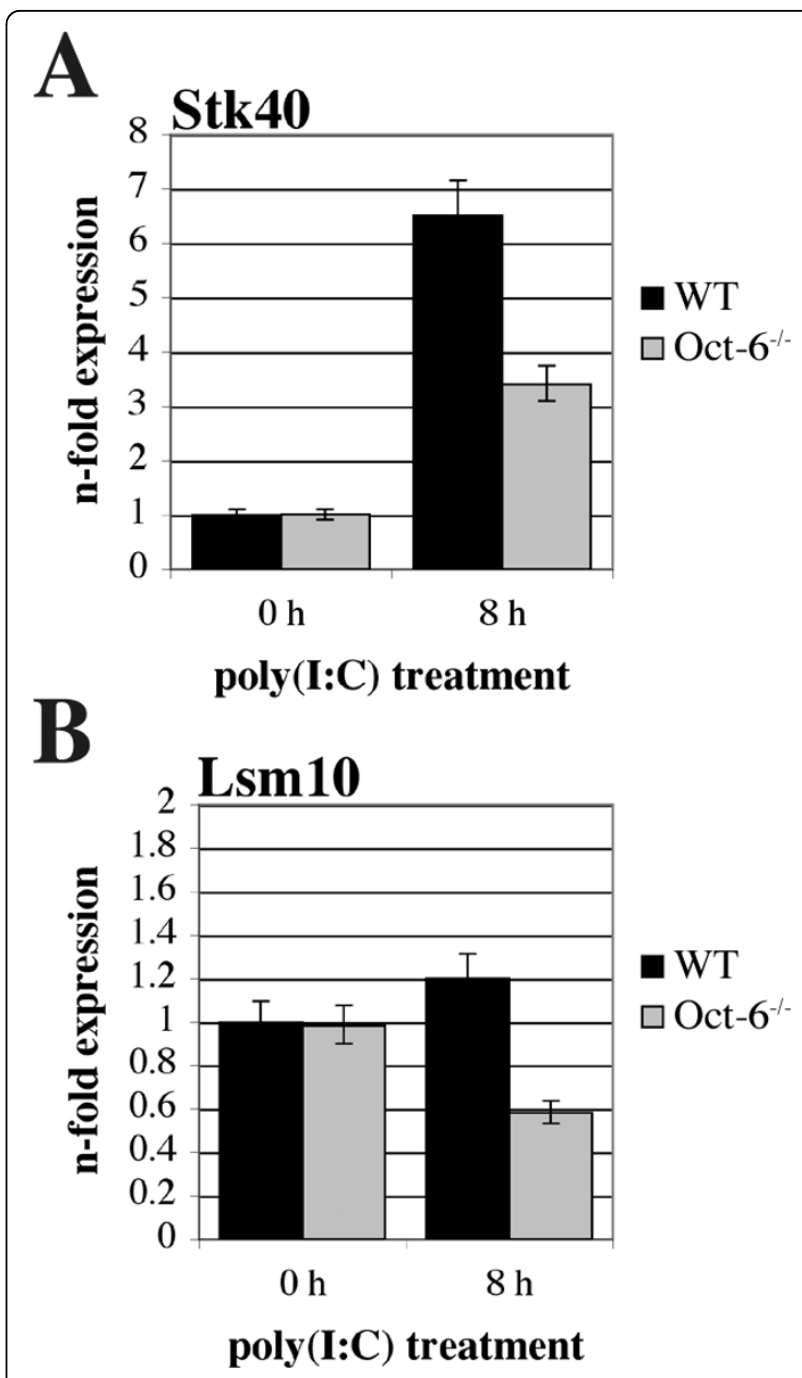

Figure 9 Expression levels of Stk40 and Lsm 10 after poly(l:C) treatment are reduced in the absence of Oct-6. WT and Oct- ${ }^{-1-}$ FLMs were treated with poly(l:C) for $8 \mathrm{~h}$ or incubated with medium alone ( 0 h). Expression levels of (A) Stk40 and (B) Lsm 10 were determined by RT-qPCR using Ube2d2 as endogenous control. Data are depicted relative to untreated WT cells. Mean values \pm SD of six experiments are shown.

binding region defined herein, an enhancer element around $12 \mathrm{~kb}$ downstream of the Oct- 6 gene mediates Oct-6 expresssion during Schwann cell development. Deletion of this enhancer element completely abolishes Oct-6 expression in Schwann cells without affecting its expression in other cell types [25,39]. Schwann cell-axonal contact induces Oct-6 expression by possibly multiple pathways [40], but transcription factors and co-activators involved are still poorly characterised. $\mathrm{NF} \kappa \mathrm{B}$ is required but not sufficient for Oct-6 expression [41] and it is at present unknown how the different signals input on the Oct- 6 enhancer element. Thus, the mechanism of gene induction is clearly different for IFN- and Schwann 
cell-axonal contact-induced Oct- 6 expression and involves distinct regulatory regions. Potential cross-influence and regulation in other cell types remain to be investigated.

Except for the ubiquitous Oct-1, expression of all POU domain proteins is regulated in a developmental and/or cell differentiation-dependent manner, with some members being lineage-specifying factors $[12,42,43]$. Inducibility of Oct- 6 in the context of innate immune responses adds a new facet to POU domain protein biology and raises the question if Oct- 6 is unique in this regard or if other members display similar as yet unrecognised modes of regulation.

Using WT and Oct6-deficient foetal liver-derived macrophages, we demonstrate that IFN $\beta$ and poly(I:C) treatment is sufficient to induce Oct- 6 expression and nuclear localisation. We could demonstrate a functional role of Oct- 6 in poly(I:C) induced transcriptional responses using microarray analysis of WT compared to Oct-6-deficient cells. 200 genes were at least two-fold differentially expressed between WT and Oct-6-deficient cells after poly(I:C) treatment. Genes affected by the absence of Oct- 6 were diverse with respect to functional annotation and no specific pathway appeared as Oct-6 regulated. Using RT-qPCR we confirmed Oct-6-dependent gene regulation for $L s m 10$ and Stk40. Interestingly, the effect of Oct- 6 on gene expression was different for these two genes. In the case of Stk40, Oct- 6 was needed for efficient upregulation, whereas it was required for the maintenance of $L s m 10$ expression after poly(I:C) treatment. The function of Stk40, also known as SINK homologous serine/threonine kinase (SHIK) and Lyk4, is poorly characterised. Very recently, $S t k 40$ has been identified as Oct-4 target gene that is required for extraembryonic endoderm differentiation [44]. On the other hand, overexpressed $S t k 40$ was shown to inhibits TNFinduced NF $\kappa \mathrm{B}$ - and p53-mediated transcription [45]. Lsm10 is a component of the U7 small nuclear ribonucleoprotein (snRNP) complex, which is involved in the formation of the 3 ' end processing of canonical histone mRNAs [46,47]. Against this background, it can be speculated that Oct-6 influences chromatin remodelling and cell cycle progression. More detailed gene expression analyses, in particular considering kinetic aspects, will certainly be required in order to fully characterise the role of Oct- 6 in innate immune responses. It will also be of major interest to determine the role of Oct-6 in innate immunity in vivo. However, since Oct- 6 deficient animals die soon after birth $[21,22]$ these studies will have to await the availability of conditional knockout mice.

Interestingly, absence of Oct- 6 in macrophages did not affect the expression of $E g r 2$ and Pmp22, genes that are regulated by Oct- 6 in Schwann cells [23,48]. Thus, target genes of Oct- 6 differ between cell types and/or stimuli. Dependent on specific DNA elements and the presence of distinct co-activators, POU proteins can assume different conformations [49]. With respect to co-activators, the SRY box protein Sox10 cooperates with Oct-6 in Schwann cells and glial cells [23,50,51]. It is reasonable to assume that distinct transcriptional coactivators are present or activated in macrophages, fibroblasts and Schwann cells and that these account for the differences in target gene expression.

It seems worth considering our results also in the context of neuropathologies. We demonstrate that Oct-6 is induced by IFN $\beta$ in the murine Schwann cell line SW10. Oct-6 protein expression was very low in this cell line, but the potency of IFNs to induce Oct- 6 might be interesting enough to prompt studies on primary Schwann cells and in vivo. In particular in the context of inflammatory and infection-induced neuropathologies, where IFNs are produced and Schwann cells de-differentiate and develop again to a myelinating phenotype. We hypothesise that IFN application or stimulation by e.g. viral infection can influence peripheral and possibly central nervous system myelination by triggering Oct- 6 expression.

\section{Conclusions}

We identify Oct-6 as an ISG and inducible protein in cell types where it has not been reported yet. In addition to the known Oct- 6 function mainly in developmental processes, our report places Oct- 6 as a transcriptional (co-) activator in the innate immune response repertoire. Furthermore, our results provide new insights into Oct-6 gene regulation with a potential impact on the control of nerve myelination.

\section{Methods}

\section{Mice and cells}

Mice deficient for Ifnar1 [52], Tyk2 [53], Stat1 [54], Irf1 [55] and IFN $\beta$ [56] were crossed for at least ten generations onto C57BL/6 background. Wild type (WT) mice (C57BL/6) were purchased from Charles River Laboratories. Mice were housed under specific pathogen-free conditions according to FELASA guidelines, except for Oct- $6^{+/-}$mice which were housed conventionally. Oct- $6^{+/-}$ mice were of mixed background [21], Oct- $6^{+/+}$littermates were used as WT controls. All animal experiments were discussed and approved by the institutional ethics committee and the Austrian laws (GZ 68.205/0204-C/GT/2007 and GZ 68.205/0233-II/10b/2009). Bone marrow-derived macrophages (BMMs) were grown in the presence of L929 conditioned medium as described [57] and used for experiments on day 7 after isolation. Foetal liver-derived macrophages (FLMs) were isolated/grown by culturing foetal liver cell suspensions (day 13.5-14.5 post conception) under the same conditions as BMMs and were used for experiments on day 6 after isolation. Primary murine 
embryonic fibroblasts (pMEFs) were isolated and grown from individual embryos at day 13.5-14.5 post conceptionem according to standard procedures [58]. MEF cell lines were grown as described [59]. SW10 cells were from ATCC (Cat. No. CRL-2766; [29]) and propagated as recommended.

\section{Reagents, treatments and infections}

Cells were treated for the indicated time points with IFN $\beta$, IFN $\gamma$ or IL-6 (all purchased from Calbiochem), or with polyinosinic-polycytidylic acid (poly(I:C), GE Healthcare). IL-6 was used at a concentration of $125 \mathrm{ng} / \mathrm{ml}$, poly(I:C) at $50 \mu \mathrm{g} / \mathrm{ml}, \mathrm{IFN} \beta$ and IFN $\gamma$ at $1000 \mathrm{U} / \mathrm{ml}$ (if not stated otherwise). Infections with Murine Cytomegalovirus (MCMV) and plaque assays were done as described previously [59].

\section{Whole cell extracts and immunoprecipitations (IP)}

Cells were lysed in $50 \mathrm{mM}$ Tris. $\mathrm{HCl}$ pH8, $150 \mathrm{mM}$ $\mathrm{NaCl}, 0.5 \%$ Nonidet P-40, 10\% glycerol, $2 \mathrm{mM}$ DTT, 0.1 $\mathrm{mM}$ EDTA, $0.2 \mathrm{mM} \mathrm{Na} \mathrm{VO}_{4}, 25 \mathrm{mM} \mathrm{NaF}, 1 \mu \mathrm{g} / \mathrm{ml}$ aprotinin, $1 \mu \mathrm{g} / \mathrm{ml}$ leupeptin and $1 \mathrm{mM}$ PMSF. Cell debris was removed by centrifugation. $1 \mathrm{mg}$ whole cell extract $/ \mathrm{ml}$ was incubated overnight with $2 \mu \mathrm{g}$ anti-Oct-6 antibody (C-20, Santa Cruz) and purified with protein-G PLUS agarose (Santa Cruz). Precipitates were separated on $8 \%$ SDS polyacrylamide gels. Proteins were blotted onto nitrocellulose membranes (GE Healthcare), detection was performed with a previously described rabbit polyclonal anti-Oct-6 antibody [60]. As an input control for IPs, whole cell extracts were analysed for panERK (pan-extracellular signal regulated kinases) expression. panERK antibody was from BD Transduction Laboratories. Anti-rabbit- and anti-mouse-IgG horse-raddish peroxidase-conjugated secondary antibodies and the $E C L^{m w}$-detection system were from GE Healthcare.

\section{Electrophoretic mobility shift assays (EMSAs)}

EMSAs were done as described previously [61] using $15 \mu \mathrm{g}$ whole cell extract and an octamer consensus motif containing oligonucleotide [62]. For supershifts, cell extracts were incubated with $1 \mu \mathrm{l}$ of the respective antibody prior to the binding reaction: anti-Oct- 6 (C-20), anti-Oct-1 (12F11), and anti-Oct-2 (C-20) (all Santa Cruz).

\section{Immunofluorescence}

Cells were grown and stimulated on glass slides, and fixed with $4 \%$ formaldehyde for 15 min (Histofix, Roth). Formaldehyde was quenched by glycine $(100 \mathrm{mM}, 15$ min), cells were permeabilised by methanol treatment $\left(-20^{\circ} \mathrm{C}, 5 \mathrm{~min}\right)$. Nonspecific binding was blocked with
1\% BSA in PBS for 1 hour. Oct- 6 was detected by incubating the slides with anti-Oct- 6 antibody (C-20, Santa Cruz; $4 \mu \mathrm{g} / \mathrm{ml}$ in blocking solution; $4^{\circ} \mathrm{C}$ overnight) and a fluorescently labelled a-goat IgG secondary antibody (Alexa-Fluor $^{\text {Tu }} 488 ; 1: 200$ in PBS; 1 hour at room temperature). Goat IgG (Invitrogen) was used as isotype control. Nuclei were counterstained with DAPI $(100 \mathrm{ng} / \mathrm{ml})$.

\section{Alignment of Oct- 6 upstream sequences and transcription factor binding site (TFBS) prediction}

For the alignments, mouse, rat and human sequences from +1 to $-5 \mathrm{~kb}$ were used (Blast 2 sequences: http://blast.ncbi. nlm.nih.gov/bl2seq/wblast2.cgi; March 2008). Mouse sequence accession number NC_000070.5 (M.m. C57BL/6, chromosome 4, reference assembly; base $124334896=+1$ on the + strand). Human sequence accession number NC_000001_10 (H.s. chromosome 1, GRCh37 primary reference assembly; base $38512450=+1$ on the -strand). Rat sequence accession number NC_005104.2 (R.n., chromosome 5, reference assembly; base $143981547=+1$ on the + strand). Homologous sequence parts, i.e. -4367 to $-4500,-1598$ to -3233 , and -161 to -637 (base counts correlate to the murine sequence), were submitted to TFBS analysis analysed using "Patch" (http://www.gene-regulation. com/pub/programs.html; August 2008), which scans input sequences for potential TFBSs based on the Transfac database. A number of Stat1- and ISGF3-binding sites were predicted for each sequence part. We decided to concentrate on the homologous sequence part nearest to the transcription start site (-161 to -637) of Oct-6, based on a report showing that the regions $-500 \mathrm{bp}$ upstream of the transcription start site of IFN-inducible genes are enriched in predicted binding sites for Stat1 and ISGF3 [63].

\section{Chromatin immunoprecipitation (ChIP)}

ChIP for Stat1 was performed as described [35] with minor modifications. Sonication (Sonopuls HD70, MS72 sonotrode; Bandelin) was performed at $50 \%$ power and $90 \%$ duty cycle for 10 times $15 \mathrm{sec}$ with 1 min break between the pulses. Equal amounts of lysate were used for Stat1 IP (4 $\mu \mathrm{l}$ Stat1-C antibody/500 $\mu$ lysate; a kind gift from Pavel Kovarik, MFPL, University of Vienna; [64]) and a control reaction using nonspecific rabbit serum (Sigma). DNA was isolated following a phenol:chloroform extraction protocol and subjected to PCR analysis. PCRs were run in a final volume of $25 \mu \mathrm{l}$ containing $300 \mathrm{nM}$ primer, $2 \mathrm{mM} \mathrm{MgCl}_{2}$, $200 \mu \mathrm{M}$ dNTPs (Fermentas), $1 \times$ Biotaq buffer, 2 U Biotaq DNA polymerase (Agrobiogen) under following cycling conditions: $5 \mathrm{~min}$ at $95^{\circ} \mathrm{C}$ for initial denaturation, followed by 35 cycles of $95^{\circ} \mathrm{C}$ for $30 \mathrm{sec}$ and $61^{\circ} \mathrm{C}$ for $1 \mathrm{~min}$. PCRs were done from all samples of the anti-Stat1 IP, the control 
IP (nonspecific rabbit serum) and from an aliquot of the initial sample input prior to the IP (input DNA). Following primers were used: ChIP_Oct6-F: GTCTCTGCTCG GAACCCGA, ChIP_Oct6_S-R: CCCACGTTCCACA CAAGCT, ChIP_Oct6_L-R: GCCCGCGTACACATTCAC; ChIP_Irf1-F: GCACAGCTGCCTTGTACTTCC, ChIP_Irf1-R: TCGGCCTCATCATTTCGG.

\section{RNA isolation and reverse transcription (RT)}

Total RNA was isolated following the TRIZOL (Invitrogen) protocol. Prior to cDNA synthesis, RNA was treated with $1 \mathrm{U} / \mu \mathrm{g}$ RNA RQ1 DNase I (Promega) in order to digest contaminating genomic DNA. cDNA was prepared from $1 \mu \mathrm{g}$ total RNA per $20 \mu \mathrm{l}$ reaction using the iScript First Strand cDNA synthesis kit (BioRad), including controls for DNA contamination (reactions without addition of reverse transcriptase).

\section{Real-time quantitative PCR (qPCR) analysis of gene expression}

Target gene expression was assessed by qPCR with ubiquitin-conjugating enzyme E2D2 (Ube2d2) as endogenous control gene. Assays for IFN $\beta$ and $U b e 2 d 2$ were described previously [59]. Taqman ${ }^{\oplus}$ probes labelled with 6-carboxyfluorescein (FAM) at the 5 'end, and a blackhole-quencher (BHQ1) at the 3'end were used. EvaGreen (Biotium) assays were used for the quantification of Oct-6, Egr2, Pmp22, Lsm10, and Stk40. Following primers were used (5' to 3'): panIFNa:fwd-CCACAGGATCACTGTGT(A/T)CCTGAGA, rev-CTGATCACCTC CCAGGCACAG, probe-AG+AA+GAA+A+C+AC+AG $+\mathrm{CC}$ (locked nuclear acids (LNAs) are indicated by a "+" in front of the respective base; [65]);

Oct-6: fwd-AGGTCCTGTTGGAGATGATATGTT, rev-TTGGGAAATGAATTGTCAAGAAA;

Egr2: fwd-GGTGACCATCTTCCCCAATG, revTTGATCATGCCATCTCCCG;

Pmp22: fwd-CCGGTTTTACATCACTGGATTCT, rev-TGTAGATGGCCGCTGCACT;

Lsm 10: fwd-CCTCCAAAAGGCCATGAGACT, revCGGGAGTTGGCTCAGAACAC;

Stk40: fwd-CTCTCAGTGCCATCATTGCATC, revCACCTTTGCCTCCTGGGA.

Taqman qPCR assays were run in a final volume of 25 $\mu \mathrm{l}$ containing $300 \mathrm{nM}$ primer (Invitrogen), $100 \mathrm{nM}$ probe (Sigma or Metabion), $200 \mu \mathrm{M}$ dNTPs (Fermentas), $4 \mathrm{mM} \mathrm{MgCl}_{2}, 1 \times$ HotFire buffer $\mathrm{B}$, and $1 \mathrm{U}$ HotFire DNA polymerase (all Solis BioDyne). The conditions were the same for the EvaGreen assays, except for the use of $0.2 \times$ EvaGreen dye instead of the probe in the presence of only $2.5 \mathrm{mM} \mathrm{MgCl} 2$. All qPCRs were run on a Mastercycler ${ }^{\ominus}$ ep Realplex (Eppendorf) applying following cycling conditions: $15 \mathrm{~min}$ at $95^{\circ} \mathrm{C}$ for initial denaturation, then 40 to 45 cycles of $95^{\circ} \mathrm{C}$ for $20 \mathrm{sec}$ and $60^{\circ} \mathrm{C}$ for $1 \mathrm{~min}$. For EvaGreen assays, the PCR was followed by a melting curve analysis in order to confirm assay specificity. Data were analysed using the Realplex software (Eppendorf) and relative target gene expression levels (i.e. $n$-fold expression levels) were calculated following the standard curve method $[66,67]$.

Statistical analysis of RT-qPCR data. RT-qPCR gene expression data were investigated for differences among genotypes and time after challenge. Univariate regression was calculated with the log of the transformed target to endogenous control gene expression ratio as dependent variable. Linear contrasts were encoded such that for each time point Oct6 ${ }^{-1-}$ were compared to WT cells. Differences among experiments were controlled for. Data were analysed with SPSS 17.0 for Mac OS-X.

\section{Microarray analysis}

WT and Oct- $6^{-1-}$ FLMs were treated with $50 \mu \mathrm{g} / \mathrm{ml}$ poly (I:C) for 8 hours in three independent experiments. RNA integrity was assessed by capillary electrophoresis using a Bioanalyser2100 (Agilent Technologies), and photometric analysis (OD260 nm/280 nm ration of $\sim 2.1$ for all samples). RNA integrity numbers (RIN) ranged between 9.2 and 9.4 indicating high quality of RNA samples. ABI1700 Mouse Genome Survey Microarrays (Applied Biosystems) in combination with the RT direct labelling kit (Applied Biosystems) were used according to the manufacturer's recommendations to generate gene expression profiles. $20 \mu \mathrm{g}$ of input total RNA was used for direct labelling and microarray hybridisation. Data transformation and normalisation: expression values less than 10 were set to 10 . Data were normalised to the $50^{\text {th }}$ percentile (intra-array normalisation) and each gene was normalised to the median expression (inter-array normalisation). Data were prefiltered based on the signal to noise ratio (cut-off level: signal above noise $>$ two-fold in all samples of the respective biological replicate group) and non-changing genes (normalised expression levels from 0,667 to 1,334 in at least 4 of 4 conditions) were subtracted. The remaining data set was tested for differentially expressed genes using ANOVA (GeneSpring Expression Analysis 7.3.1 tool, Agilent Technologies). A p-value of $p<0.05$ (Welch t-test) was considered significant. Expression differences of at least two-fold were considered relevant. Not fully annotated probes, i.e. probes that did not correspond to a NCBI RefSeq, EST or RIKEN cDNA, were excluded. Functional annotation and clustering of the differentially regulated genes was performed using the Gene Functional Classification tool of the database for annotation, visualisation and integrated discovery (DAVID; http://david.abcc. 
ncifcrf.gov/[68,69]). The array data have been deposited in the Gene Expression Omnibus database, http://www.ncbi. nlm.nih.gov/geo (GEO accession no. GSE22691).

\section{Additional material}

Additional file 1: Oct-6 protein is expressed in pMEFs in response to IFN $\beta$ treatment. Bandshift assays including supershifts with $\alpha$-Oct-1, $\alpha$-Oct- 2 and $\alpha$-Oct- 6 antibodies and Oct- $\sigma^{-1-}$ MEFs as controls.

Additional file 2: Expression of Oct-6 during MCMV infection is largely dependent on type I IFN and Jak/Stat signalling. Bandshift assays of whole cell extracts from WT, IFN $\beta^{-1-}$, Ifnar $1^{-1-}$, Tyk $2^{-/}$, and Stat $1^{-1-}$ macrophages infected with MCMV.

Additional file 3: Oct-6 DNA-binding activity in response to IFN $\beta$ or poly $(\mathrm{I}: \mathrm{C})$ treatment in foetal liver- and bone marrow-derived macrophages.

Additional file 4: Overexpression of Oct-6 in pMEFs enhances the expression of IFN $\beta$ and IFN $\alpha$ mRNAs, but does not influence the expression of Egr2 and Pmp22 mRNAs.

Additional file 5: Absence of Oct-6 does not influence the expression patterns of panIFN $\alpha$, IFN $\beta$, Egr2 and Pmp22 mRNAs upon DNA transfection in MEFs. Comparison of transfected WT and

Oct6-deficient foetal liver-derived macrophages.

Additional file 6: Absence of Oct-6 in macrophages has no impact on MCMV replication at a $\mathbf{M O I}$ of $\mathbf{0 . 1}$. Comparison of MCMV

replication in WT and Oct-6-deficient foetal liver-derived macrophages at a lower MOI.

Additional file 7: Differentially expressed genes as determined by microarray analysis that could be functionally annotated (96 out of 200; WT vs. Oct- $6^{-1}$, at least 2-fold difference, $p<0.05$ ).

Additional file 8: Complete list of differentially expressed genes (WT vs. Oct- $6^{-1-}$, at least 2 -fold difference, $p<0.05$ ).

Additional file 9: 3A (sheet 1): Gene Ontology categories upregulated by poly $(\mathrm{l}: \mathrm{C})$ treatment in WT cells $(p<0.05)$; 3B (sheet 2): Gene Ontology categories down-regulated by poly $(1: C)$ treatment in WT cells $(p<0.05)$.

\section{List of abbreviations}

BMMs: bone marrow-derived macrophages; FLMs: foetal liver-derived macrophages; Egr2: early growth response protein 2; GAS: IFN $\gamma$ activated sequence; IFN: interferon; Ifnar1: IFN $/ \beta$ receptor 1; ISRE: interferon stimulated response element; Lsm10: U7 snRNP-specific Sm-like protein LSM10; MCMV: Murine Cytomegalovirus; pMEFs: primary murine embryonic fibroblasts; Pmp22: peripheral myelin protein 22; POU-family: Pit-Oct-Uncfamily; Stat1: signal transducer and activator of transcription 1; Stk40: serine/ threonine kinase 40; Tyk2: tyrosine kinase 2; WT: wildtype.

\section{Authors' contributions}

EH performed most of the experiments, participated in the design of the study and wrote the first draft of the manuscript. UR performed the mouse routine and experimental breeding, contributed to the establishment of FLM cultures and helped with the microscopy. CGa initially identified Oct- 6 as an IFN regulated gene and performed some of the experiments with fibroblasts. CGu supervised the microarray experiment and performed the statistical analysis. DM provided the Oct- $6^{+/-}$mice and the Oct- 6 antibodies and participated in the interpretation of initial data. MM contributed to the design and co-ordination of the study. BS co-ordinated and designed the study and wrote the manuscript together with $\mathrm{EH}$ and MM. All authors read and approved the final manuscript.

\section{Acknowledgements}

We thank Claus Vogl for the supervision of statistical analysis of RT-qPCR data and Ralf Steinborn for help with the design of qPCR assays (both
University of Veterinary Medicine, Vienna). This work was supported by the Austrian Science Fund (FWF, SFB-28 to MM/BS).

\section{Author details}

'Institute of Animal Breeding and Genetics, University of Veterinary Medicine Vienna, Vienna, Austria. ${ }^{2}$ Center for Medical Research, Medical University of Graz, Graz, Austria. ${ }^{3}$ Department of Cell Biology and Genetics, ErasmusMC, Rotterdam, Netherlands. ${ }^{4}$ Biomodels Austria, University of Veterinary Medicine Vienna, Vienna, Austria. ${ }^{5}$ Department of Forensic Medicine, Medical University of Vienna, Austria.

Received: 21 April 2010 Accepted: 5 August 2010

Published: 5 August 2010

\section{References}

1. Krause CD, Pestka S: Historical developments in the research of interferon receptors. Cytokine Growth Factor Rev 2007, 18(5-6):473-482.

2. Decker T, Muller M, Stockinger S: The yin and yang of type I interferon activity in bacterial infection. Nat Rev Immunol 2005, 5(9):675-687.

3. Schindler C, Levy DE, Decker T: JAK-STAT signaling: from interferons to cytokines. J Biol Chem 2007, 282(28):20059-20063.

4. Platanias LC: Mechanisms of type-I- and type-II-interferon-mediated signalling. Nat Rev Immunol 2005, 5(5):375-386.

5. Decker T, Kovarik P, Meinke A: GAS elements: a few nucleotides with a major impact on cytokine-induced gene expression. J Interferon Cytokine Res 1997, 17(3):121-134.

6. Matsumoto M, Tanaka N, Harada H, Kimura T, Yokochi T, Kitagawa M, Schindler C, Taniguchi T: Activation of the transcription factor ISGF3 by interferon-gamma. Biol Chem 1999, 380(6):699-703.

7. Zimmermann A, Trilling M, Wagner M, Wilborn M, Bubic I, Jonjic S, Koszinowski U, Hengel H: A cytomegaloviral protein reveals a dual role for STAT2 in IFN-\{gamma\} signaling and antiviral responses. J Exp Med 2005, 201(10):1543-1553.

8. Schroder K, Hertzog PJ, Ravasi T, Hume DA: Interferon-gamma: an overview of signals, mechanisms and functions. J Leukoc Biol 2004, 75(2):163-189.

9. van Boxel-Dezaire AH, Rani MR, Stark GR: Complex modulation of cell type-specific signaling in response to type I interferons. Immunity 2006, 25(3):361-372.

10. Der SD, Zhou A, Williams BR, Silverman RH: Identification of genes differentially regulated by interferon alpha, beta, or gamma using oligonucleotide arrays. Proc Natl Acad Sci USA 1998, 95(26):15623-15628.

11. de Veer MJ, Holko M, Frevel M, Walker E, Der S, Paranjape JM, Silverman RH, Williams BR: Functional classification of interferon-stimulated genes identified using microarrays. J Leukoc Biol 2001, 69(6):912-920.

12. Phillips $K$, Luisi B: The virtuoso of versatility: POU proteins that flex to fit. J Mol Biol 2000, 302(5):1023-1039.

13. Ryan AK, Rosenfeld MG: POU domain family values: flexibility, partnerships, and developmental codes. Genes Dev 1997, 11(10):1207-1225.

14. Scholer HR, Hatzopoulos AK, Balling R, Suzuki N, Gruss P: A family of octamer-specific proteins present during mouse embryogenesis: evidence for germline-specific expression of an Oct factor. EMBO J 1989, 8(9):2543-2550.

15. Meijer D, Graus A, Kraay R, Langeveld A, Mulder MP, Grosveld G: The octamer binding factor Oct6: CDNA cloning and expression in early embryonic cells. Nucleic Acids Res 1990, 18(24):7357-7365.

16. Monuki ES, Weinmaster G, Kuhn R, Lemke G: SCIP: a glial POU domain gene regulated by cyclic AMP. Neuron 1989, 3(6):783-793.

17. He X, Treacy MN, Simmons DM, Ingraham HA, Swanson LW, Rosenfeld MG: Expression of a large family of POU-domain regulatory genes in mammalian brain development. Nature 1989, 340(6228):35-41.

18. Faus I, Hsu HJ, Fuchs E: Oct-6: a regulator of keratinocyte gene expression in stratified squamous epithelia. Mol Cell Biol 1994, 14(5):3263-3275

19. Andersen B, Weinberg WC, Rennekampff $O$, McEvilly RJ, Bermingham JR, Hooshmand F, Vasilyev V, Hansbrough JF, Pittelkow MR, Yuspa SH, et al: Functions of the POU domain genes Skn-1a/i and Tst-1/Oct-6/SCIP in epidermal differentiation. Genes Dev 1997, 11(14):1873-1884. 
20. Baumeister $H$, Meyerhof $W$ : The POU domain transcription factor Tst-1 activates somatostatin receptor 1 gene expression in pancreatic beta -cells. J Biol Chem 2000, 275(37):28882-28887.

21. Jaegle M, Mandemakers W, Broos L, Zwart R, Karis A, Visser P, Grosveld F, Meijer D: The POU factor Oct-6 and Schwann cell differentiation. Science 1996, 273(5274):507-510.

22. Bermingham JR Jr, Scherer SS, O'Connell S, Arroyo E, Kalla KA, Powell FL, Rosenfeld MG: Tst-1/Oct-6/SCIP regulates a unique step in peripheral myelination and is required for normal respiration. Genes Dev 1996, 10(14):1751-1762.

23. Ghislain J, Charnay P: Control of myelination in Schwann cells: a Krox20 cis-regulatory element integrates Oct6, Brn2 and Sox10 activities. EMBO Rep 2006, 7(1):52-58.

24. Svaren J, Meijer D: The molecular machinery of myelin gene transcription in Schwann cells. Glia 2008, 56(14):1541-1551

25. Ghazvini M, Mandemakers W, Jaegle M, Piirsoo M, Driegen S, Koutsourakis M, Smit X, Grosveld F, Meijer D: A cell type-specific allele of the POU gene Oct- 6 reveals Schwann cell autonomous function in nerve development and regeneration. EMBO J 2002, 21(17):4612-4620.

26. Ryu EJ, Wang JY, Le N, Baloh RH, Gustin JA, Schmidt RE, Milbrandt J: Misexpression of Pou3f1 results in peripheral nerve hypomyelination and axonal loss. J Neurosci 2007, 27(43):11552-11559.

27. Schreiber J, Enderich J, Sock E, Schmidt C, Richter-Landsberg C, Wegner M: Redundancy of class III POU proteins in the oligodendrocyte lineage. $J$ Biol Chem 1997, 272(51):32286-32293.

28. Jensen NA, Pedersen KM, Celis JE, West MJ: Neurological disturbances, premature lethality, and central myelination deficiency in transgenic mice overexpressing the homeo domain transcription factor Oct-6. J Clin Invest 1998, 101(6):1292-1299.

29. Hai M, Muja N, DeVries GH, Quarles RH, Patel PI: Comparative analysis of Schwann cell lines as model systems for myelin gene transcription studies. J Neurosci Res 2002, 69(4):497-508.

30. Dunn TL, Ross IL, Hume DA: Transcription factor Oct-2 is expressed in primary murine macrophages. Blood 1996, 88(10):4072.

31. Honda K, Taniguchi T: IRFs: master regulators of signalling by Toll-like receptors and cytosolic pattern-recognition receptors. Nat Rev Immunol 2006, 6(9):644-658.

32. Doyle SL, O'Neill LA: Toll-like receptors: from the discovery of NFkappaB to new insights into transcriptional regulations in innate immunity. Biochem Pharmacol 2006, 72(9):1102-1113.

33. Takeuchi O, Akira S: MDA5/RIG-I and virus recognition. Curr Opin Immunol 2008, 20(1):17-22.

34. Levy DE, Marie I, Smith E, Prakash A: Enhancement and diversification of IFN induction by IRF-7-mediated positive feedback. J Interferon Cytokine Res 2002, 22(1):87-93.

35. Sadzak I, Schiff M, Gattermeier I, Glinitzer R, Sauer I, Saalmuller A, Yang E, Schaljo B, Kovarik P: Recruitment of Stat1 to chromatin is required for interferon-induced serine phosphorylation of Stat1 transactivation domain. Proc Natl Acad Sci USA 2008, 105(26):8944-8949.

36. Baranek C, Sock E, Wegner M: The POU protein Oct- 6 is a nucleocytoplasmic shuttling protein. Nucleic Acids Res 2005, 33(19):6277-6286.

37. Sock E, Enderich J, Rosenfeld MG, Wegner M: Identification of the nuclear localization signal of the POU domain protein Tst-1/Oct6. J Biol Chem 1996, 271(29):17512-17518.

38. Mesplede T, Island ML, Christeff N, Petek F, Doly J, Navarro S: The POU transcription factor Oct-1 represses virus-induced interferon $A$ gene expression. Mol Cell Biol 2005, 25(19):8717-8731.

39. Mandemakers W, Zwart R, Jaegle M, Walbeehm E, Visser P, Grosveld F, Meijer D: A distal Schwann cell-specific enhancer mediates axonal regulation of the Oct- 6 transcription factor during peripheral nerve development and regeneration. EMBO J 2000, 19(12):2992-3003.

40. Meijer D: Neuroscience. Went fishing, caught a snake. Science 2009, 325(5946):1353-1354.

41. Nickols JC, Valentine W, Kanwal S, Carter BD: Activation of the transcription factor NF-kappaB in Schwann cells is required for peripheral myelin formation. Nat Neurosci 2003, 6(2):161-167.

42. Welstead GG, Brambrink T, Jaenisch R: Generating iPS cells from MEFS through forced expression of Sox-2, Oct-4, c-Myc, and Klf4. J Vis Exp 2008, 14.
43. Vierbuchen T, Ostermeier A, Pang ZP, Kokubu Y, Sudhof TC, Wernig M: Direct conversion of fibroblasts to functional neurons by defined factors. Nature 2010, 463(7288):1035-1041.

44. Li L, Sun L, Gao F, Jiang J, Yang Y, Li C, Gu J, Wei Z, Yang A, Lu R, et al: Stk40 links the pluripotency factor Oct4 to the Erk/MAPK pathway and controls extraembryonic endoderm differentiation. Proc Natl Acad Sci USA 2010, 107(4):1402-1407.

45. Huang J, Teng L, Liu T, Li L, Chen D, Li F, Xu LG, Zhai Z, Shu HB: Identification of a novel serine/threonine kinase that inhibits TNFinduced NF-kappaB activation and p53-induced transcription. Biochem Biophys Res Commun 2003, 309(4):774-778.

46. Pillai RS, Will CL, Luhrmann R, Schumperli D, Muller B: Purified U7 snRNPs lack the Sm proteins D1 and D2 but contain Lsm10, a new 14 kDa Sm D1-like protein. EMBO J 2001, 20(19):5470-5479.

47. Yang XC, Torres MP, Marzluff WF, Dominski Z: Three proteins of the U7-specific Sm ring function as the molecular ruler to determine the site of 3 '-end processing in mammalian histone pre-mRNA. Mol Cell Biol 2009, 29(15):4045-4056.

48. Monuki ES, Kuhn R, Lemke G: Repression of the myelin P0 gene by the POU transcription factor SCIP. Mech Dev 1993, 42(1-2):15-32.

49. Remenyi A, Tomilin A, Scholer HR, Wilmanns M: Differential activity by DNA-induced quarternary structures of POU transcription factors. Biochem Pharmacol 2002, 64(5-6):979-984.

50. Kuhlbrodt K, Herbarth B, Sock E, Enderich J, Hermans-Borgmeyer I, Wegner M: Cooperative function of POU proteins and SOX proteins in glial cells. J Biol Chem 1998, 273(26):16050-16057.

51. Reiprich S, Kriesch J, Schreiner S, Wegner M: Activation of Krox20 gene expression by Sox10 in myelinating Schwann cells. J Neurochem 2009.

52. Muller U, Steinhoff U, Reis LF, Hemmi S, Pavlovic J, Zinkernagel RM, Aguet M: Functional role of type I and type II interferons in antiviral defense. Science 1994, 264(5167):1918-1921.

53. Karaghiosoff $M$, Neubauer $H$, Lassnig $C$, Kovarik $P$, Schindler $H$, Pircher $H$ McCoy B, Bogdan C, Decker T, Brem G, et al: Partial impairment of cytokine responses in Tyk2-deficient mice. Immunity 2000, 13(4):549-560.

54. Durbin JE, Hackenmiller R, Simon MC, Levy DE: Targeted disruption of the mouse Stat 1 gene results in compromised innate immunity to viral disease. Cell 1996, 84(3):443-450.

55. Reis LF, Ruffner H, Stark G, Aguet M, Weissmann C: Mice devoid of interferon regulatory factor 1 (IRF-1) show normal expression of type I interferon genes. EMBO J 1994, 13(20):4798-4806.

56. Erlandsson L, Blumenthal R, Eloranta ML, Engel H, Alm G, Weiss S, Leanderson $\mathrm{T}$ : Interferon-beta is required for interferon-alpha production in mouse fibroblasts. Curr Biol 1998, 8(4):223-226.

57. Baccarini M, Bistoni F, Lohmann-Matthes ML: In vitro natural cell-mediated cytotoxicity against Candida albicans: macrophage precursors as effector cells. J Immunol 1985, 134(4):2658-2665.

58. Todaro GJ, Green H: Quantitative studies of the growth of mouse embryo cells in culture and their development into established lines. J Cell Biol 1963, 17:299-313.

59. Strobl B, Bubic I, Bruns U, Steinborn R, Lajko R, Kolbe T, Karaghiosoff M, Kalinke $U$, Jonjic S, Muller M: Novel functions of tyrosine kinase 2 in the antiviral defense against murine cytomegalovirus. J Immunol 2005, 175(6):4000-4008.

60. Zwart R, Broos L, Grosveld G, Meijer D: The restricted expression pattern of the POU factor Oct- 6 during early development of the mouse nervous system. Mech Dev 1996, 54(2):185-194.

61. Lillemeier BF, Koster M, Kerr IM: STAT1 from the cell membrane to the DNA. EMBO J 2001, 20(10):2508-2517.

62. Jaegle M, Ghazvini M, Mandemakers W, Piirsoo M, Driegen S, Levavasseur F, Raghoenath S, Grosveld F, Meijer D: The POU proteins Brn-2 and Oct-6 share important functions in Schwann cell development. Genes Dev 2003, 17(11):1380-1391.

63. Ananko EA, Kondrakhin YV, Merkulova TI, Kolchanov NA: Recognition of interferon-inducible sites, promoters, and enhancers. BMC Bioinformatics 2007, 8:56.

64. Kovarik P, Stoiber D, Novy M, Decker T: Stat1 combines signals derived from IFN-gamma and LPS receptors during macrophage activation. EMBO J 1998, 17(13):3660-3668.

65. Letertre C, Perelle S, Dilasser F, Arar K, Fach P: Evaluation of the performance of LNA and MGB probes in 5'-nuclease PCR assays. Mol Cell Probes 2003, 17(6):307-311. 
66. Giulietti A, Overbergh L, Valckx D, Decallonne B, Bouillon R, Mathieu C: An overview of real-time quantitative PCR: applications to quantify cytokine gene expression. Methods 2001, 25(4):386-401.

67. Karaghiosoff M, Steinborn R, Kovarik P, Kriegshauser G, Baccarini M, Donabauer B, Reichart U, Kolbe T, Bogdan C, Leanderson T, et al: Central role for type I interferons and Tyk2 in lipopolysaccharide-induced endotoxin shock. Nat Immunol 2003, 4(5):471-477.

68. Dennis G, Sherman BT, Hosack DA, Yang J, Gao W, Lane HC, Lempicki RA: DAVID: Database for Annotation, Visualization, and Integrated Discovery. Genome Biol 2003, 4(5):P3.

69. Huang da W, Sherman BT, Lempicki RA: Systematic and integrative analysis of large gene lists using DAVID bioinformatics resources. Nat Protoc 2009, 4(1):44-57.

doi:10.1186/1471-2121-11-61

Cite this article as: Hofmann et al:: Octamer-binding factor 6 (Oct- 6 /

Pou3f1) is induced by interferon and contributes to dsRNA-mediated transcriptional responses. BMC Cell Biology 2010 11:61.

\section{Submit your next manuscript to BioMed Central} and take full advantage of:

- Convenient online submission

- Thorough peer review

- No space constraints or color figure charges

- Immediate publication on acceptance

- Inclusion in PubMed, CAS, Scopus and Google Scholar

- Research which is freely available for redistribution

Submit your manuscript at www.biomedcentral.com/submit
C Biomed Central 